\title{
Experiment on Rotational Motion of Charged Particle
}

\author{
Hirofumi Kojima, Kota Hattori, and Toshiaki Yokota
}

\begin{abstract}
Fine particle plasma has large charge in comparison with gaseous plasma and indicates various singular behaviors due to strongly coupled character. Research of fine particle plasma is not only useful for investigation of space phenomena (formation and behavior of planetary ring) but also contains various possibilities of application through control of particles. As part of such purpose, we experiment that negatively charged particle irradiated by electron beam is confined and makes rotation in logarithmic potential around coaxial cylindrical electrodes. Particles used in this experiment are volcanic ashes of Mt. Usu and we used particles with radius of $90 \mu \mathrm{m}$ measured diameter by laser scattering and sorted by wind tunnel. In the experiment, we could confirm orbital motion of particle around central electrode by adding positively voltage to central electrode. By analyzing motion of particle in VTR pictures recorded this motion, we can calculate mass-to-charge ratio, and particle charged one estimated to be several thousand electrons.
\end{abstract}

Keywords: Fine particle plasma, Laser scattering, Kingdontrap, Rotational motion

\section{1.はじめに}

宇宙空間には多数の微粒子が存在し、それらが電荷を 獲得して微粒子プラズマの状態になっている。土星や木 星の惑星リングがこの状態で、また、地球上でも核融合 プラズマやプロセシングプラズマ中に微粒子が発生、混 入し微粒子プラズマ状態になっていると考えられている。 微粒子プラズマとは、気体プラズマ中で微粒子が電荷 を獲得して混在している状態もしくは、正および負に帯 電した微粒子が混在している状態の総称である。この微 粒子プラズマに関わる諸現象老研究する上で、微粒子の 粒子径や帯電量を知る事が重要である。そこで、我々の 研究室では、粒子径や帯電量をリアルタイムで測定でき る方法老研究している。測定手段として、粒子径測定に はHe-Neレーザーによる散乱強度比を測定し、帯電量
測定の 1 つの方法としてキングダムトラップによっ て、それぞれ粒子径と帯電量を测定する実験を行った。

2. 粒子往测定

\section{1 風洞}

風洞は断面が正方形の空洞になっており、一方の端 にファンが取り付けられ、横方向から一定速度の風が 送り込まれる。上部に取り付けられたドロッパーから 粒子を落下させることにより、等しい密度の粒子を粒 子径ごとにふるい分けることができる装置である。こ の装置老用い、平均直径 $10 \mu \mathrm{m} \sim 400 \mu \mathrm{m}$ の火山灰粒 子を 25 個のセルに選別し、セルごとに電子顕微鏡で 撮影した画像（Fig.1）をもとに、粒子径を測定した結 
果をグラフに示す (Fig. 2)。さらに、平均直径 $90 \mu \mathrm{m}$ の粒子をメッシュによるふるいわけ法によって選別す る事ができ、その粒子を平均直径 $60 \mu \mathrm{m}$ 以下と $90 \mu$ $\mathrm{m}$ の粒子に選別できた。

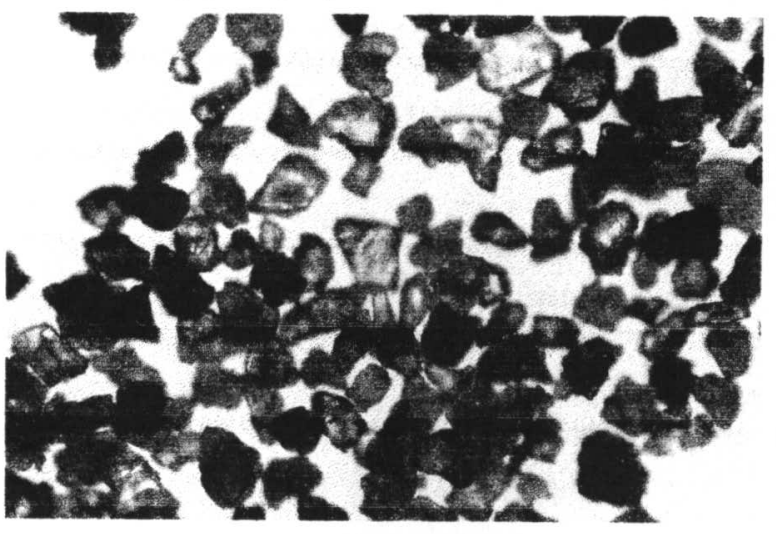

Fig. 1 電子顕微鏡の画像

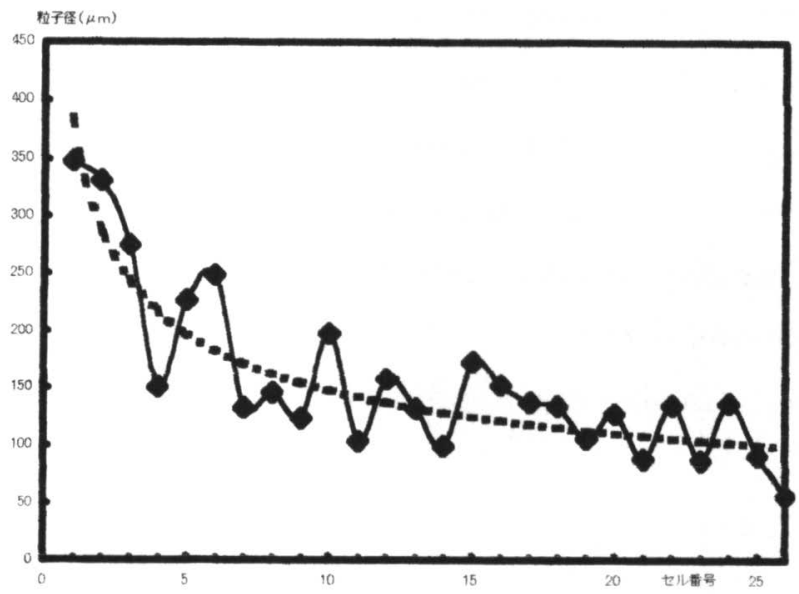

Fig.2 風洞による選別粒子の粒子径

\section{2 レーザー散乱による粒子径測定}

$\mathrm{He}-\mathrm{Ne}$ レーザーから照射された光はビームエキス パンダーで直径が拡大されレンズを通過し、試料を 入れた容器の中心に焦点が合わせられる。粒子によ って散乱されずに通過したレーザーは、ガラス板を 貼り付けた銅板により 90 度の向きに反射され、フ オトダイオード 2 に入射する。そのレーザーの強度 を $I_{2}$ とする。粒子によって散乱されたレーザーは、 銅板の周囲を通過してフォトダイオード 1 に入射す る。そのレーザーの強度を $I_{1}$ とする。光の強度をフ
オトダイオードで検出しオシロスコープに表示させ、 それぞれの強度を読み取り強度の比 $I_{1} / I_{2}$ を測定す る。粒子径が大きくなるにつれて、レーザー光の散 乱強度が増加し、非散乱強度が減少する。あらかじ め粒子径に対する強度比がわかっていれば、未知の 粒子径の強度比 $I_{1} I I_{2}$ を測定することによって、そ の粒子の粒子径が得られる。

\section{3 実験方法}

まず初めに、標淮粒子 $0.2,0.5,1,5,8,10,20,40$ $\mu \mathrm{m}$ を用い、散乱強度比 $I_{1} / I_{2}$ と粒子径の関係をグ ラフにプロットし較正曲線を描く。次に、電子顕微 鏡で測定した平均直径 $90 \mu \mathrm{m}$ 以下の火山灰粒子を 同様の方法で測定し散乱強度比を求め、標準粒子の 較正曲線上にプロットした（Fig.3）。

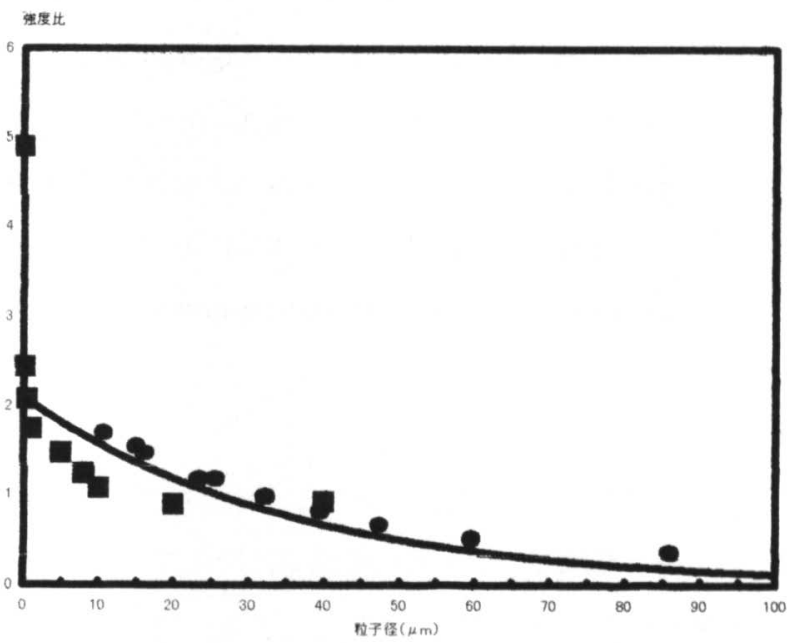

Fig.3 火山灰粒子の較正曲線上へのプロット

\section{4 実験結果}

Fig.2 より、粒子が落下する地点のセルの番号を 1 として、セルの番号が大きくなるにつれて緩やかで はあるが粒子径が減少していっているのがわかる。

Fig. 3 より、60 $\mu \mathrm{m}$ 以下の火山灰粒子をレーザー散 乱で測定した結果、 $10 \mu \mathrm{m}$ 以上 $90 \mu \mathrm{m}$ 以下という 結果が出た。これは、顕微鏡で測定した結果とほぼ 等しいといえる。 


\section{3. 带電量測定}

3.1 キングダムトラップ

キングダムトラップは、直径 $10 \mathrm{~mm}$ の中心電極と 直径 $72 \mathrm{~mm}$ の外部円筒電極の二つの同軸円筒電極か ら成っている。これらの電極間に電位差を与えると、 中心電極に対して半径方向の対数ポテンシャルが形 成され、带雪微粒子は中心電極の周りで軌道運動し ながらトラップされる。トラップされた粒子の軌道 を円軌道に限定した場合には、次の関係式が覓かれ 万。

$$
\frac{q}{m}=\frac{\omega^{2} r_{c}^{2} \ln \left(r_{1} / r_{2}\right)}{V}
$$

ここで、 $V$ を電極間電位差、 $\omega$ を角振動数、 $r_{c}$ を軌 道半径、 $r_{1}$ と $r_{2}$ を外部電極と中心電極の半径とする。 このことから、軌道半径と振動数を測定することに より、微粒子の質量電荷比を得ることができる。

\section{2 実跧装置}

十字型の $20 \mathrm{~cm} \times 30 \mathrm{~cm}$ と $30 \mathrm{~cm} \times 30 \mathrm{~cm}$ のガラス 真空チェンバーを組み合わせ、帯電微粒子生成部と 微粒子閉じ込め部で構成されている。真空排気装膡 は、油回転ポンプと油搪散ポンプを使用し、6×10${ }^{6}$ torr 程度の真空度を得ることができる。

帯電微粒子生成部には、ドロッパーと電子鋶が㒄 え付けられている。微粒子は、ドロッパーの振動に より振るい落とされ、電子ビーム照射領域を通過す ることにより、負に帯電する。その後、自由落下に より闒じ込め部に導かれる。

閉じ込め部には、キングダムトラップが備え付け られ、微粒子はここでトラップされる。トラップ微 粒子は、白色 LED ライトによって照らされ、軌道 面に垂直に撮影されたデジタルビデオカメラの画像 によって軌道運動が解析される。

\section{3 実験方法}

粒子には、前章の粒子径測定で選別された平均直 径 $90 \mu \mathrm{m}$ の火山灰粒子を用いる。このようにする ことで、粒子径のばらつきによる带電量の誤差を小 さくする事ができる。

チェンバーを $6 \times 10{ }^{6}$ torr に排気し、電極間電位 差は 0 6500V、電子銃の加速電在は 0〜1500V で 変化させ実験を行う。電子ビ一ム照射によって負に 带電した微粒子が、キングダムトラップ中に閉じ込 められ軌道運動が始まる。この軌道運動の振動数と 勒道半径を測定し、微粒子の質量電荷比を求める。

\section{4 実験結果}

キングダムトラップに入射した带電微絃子ゆ運動 の画像を解析することにより、次のような結果が得 られた。

（1）微粒子が中心電極の周りで、円軌道又は楕円軌 道を描きながらトラップされるのが確認された。 また、中心電極から遠ざかる微粒子も確認され た。これは、二次電子放出のために正に带電し た微粒子が存在するためであると考えられる。

（2）軌道運動の寿命は、最大で 3 回転、最小で 0.5 回転であった。また、2 個の微粒子が同時にト ラップされたものも確認された。

（3）画像をもとに軌道運動の解析を行った結果、回 転半径 $r_{c}=6.50 \sim 18.1(\mathrm{~mm})$ 、振動数 $f=14 \sim$ 30( $\mathrm{Hz})$ であった。

（4）以上の結果加ら、質量電荷比 $q / m=5.70 \times 10^{4} \sim$ $3.15 \times 10^{3}(\mathrm{C} / \mathrm{kg})$ 、よって微粒子には $3.10 \times 10^{6}$ $\sim 1.68 \times 10^{7}$ 個の電子が付着していることが確 認された。

また、典型的な粒子の軌道運動の例として、Fig.4 ではトラップされた微粒子の画像を、Fig.5 では 2 個の微粒子が同時にトラップされた画像を示した。 


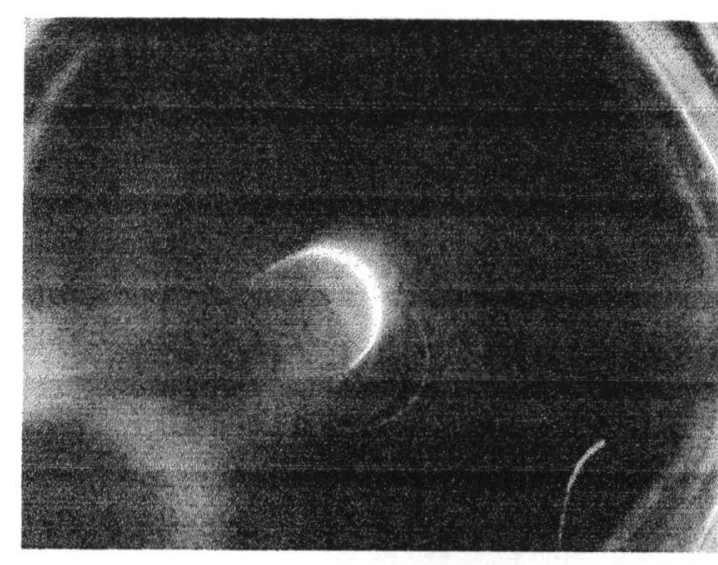

Fig.4 トラップされた粒子（中央の円弧を描い ている部分がトラップされた粒子の軌道)

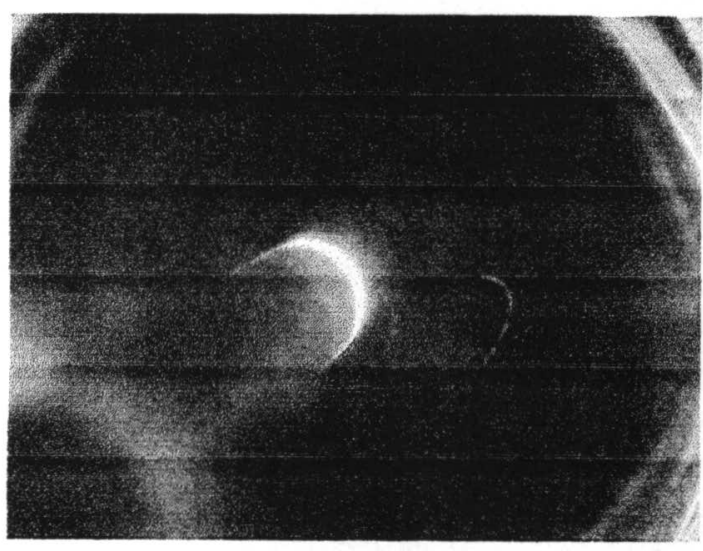

Fig.5 同時にトラップされた粒子（中心電極から 右方向の 2 つの円弧が同時にトラップされた粒子の軌道)

Fig.4 は、電極館電位差が $3200 V$ 、電子銃の加速電 圧が $1000 \mathrm{~V}$ のものである。粒子の軌道から、 $r_{c}=11.5$ $\mathrm{mm}$ 、振動数 $f=30 \mathrm{~Hz} 、 q / \mathrm{m}=3.15 \times 10-{ }^{3} \mathrm{C} / \mathrm{kg}$ 、よ 3) つて $1.7 \times 10^{7}$ 個の電子が付着している。

Fig. 5 は、電極館電位差が $3400 \mathrm{~V}$ 、電子銃の加速電 圧が $1000 \mathrm{~V}$ のものである。粒子の軌道から、中心 電極により近い方の粒子は、 $r_{c}=8.00 \mathrm{~mm}$ 、振動数 $f=30 \mathrm{~Hz} 、 q / m=1.32 \times 10-{ }^{3} \mathrm{C} / \mathrm{kg}$ 、よって $6.8 \times 10^{6}$ 個の電子が付着している。他方の粒子では、 $r_{c}=17.0$ $\mathrm{mm}$ 、振動数 $f=20 \mathrm{~Hz} 、 q / m=2.64 \times 10-{ }^{3} \mathrm{C} / \mathrm{kg}$ 、よ って $1.65 \times 10^{7}$ 個の電子が付着している。

\section{4. 結論}

実験から、以下のようなことが分かった。

平均直径 $10 \mu \mathrm{m} \sim 400 \mu \mathrm{m}$ の火山灰粒子を大まか ながら風洞によって、粒子径ごとに選別することが できた。さらに、未知の粒子のレーザー散乱強度比 を測定し較正曲線上にプロットすることにより、粒 子径を推定できることが確認できた。また、電子ビ 一ムによって帯電した粒径 $90 \mu \mathrm{m}$ 程度の微粒子は、 $10^{6} e$ 程度の電荷を持つことが確認できた。

以上のように、微粒子の粒子径と帯電量をリアル タイムで測定するために、レーザー散乱とキングダ ムトラップの方法を用いる事が有効であると確認で きた。今後、実際に微粒子プラズマ中の微粒子の粒 子径と帯電量を測定するためには、微粒子の形状を 考慮に入れる事や軌道の寿命をさらに長くすること が必要であると考えられる。

\section{参考文献}

1) 横田俊昭 著 微粒子プラズマの生成と素過程の研究 基䃈研究 (C)(2) 研究成果報告書(No.07808052)

2) 横田俊昭 著 ダストプラズマの現状と課題 Journal of Plasma and Fusion Research Vol. 73, No. 11 (1997), pp. 1220 1261

Carole Smetana, David Alexander, Scott Robertson, Kim Vilkaitis and Bob Walch, American Association of Physics Teachers, A spherical electrostatic orrery Am. J. Phys.64(11), November 1996

L. Mees, G. Grehan, G, Gouesbed. Optics Communications 194 (2001) 59-65, Time-resolved scattering diagram for a sphere illuminated by plane wave and focused short pulse

5)
粉体工学会 編 粒子径測定技術
日刊工業新聞社 1994 年 